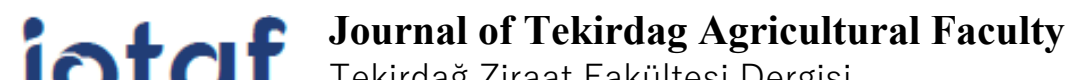 \\ Tekirdağ Ziraat Fakültesi Dergisi
}

\section{Determination of Energy Balance and Greenhouse Gas Emissions (GHG) of Cotton Cultivation in Turkey: A Case Study from Bismil District of Diyarbakır Province}

Türkiye'de Pamuk Yetiştiriciliğinin Enerji Bilançosu ve Sera Gazı Emisyonlarının Belirlenmesi: Diyarbakır İli Bismil İlçesi Örneği

\section{Mehmet Firat BARAN $^{1 *}$, Osman GÖKDOĞAN ${ }^{2}$, Yılmaz BAYHAN ${ }^{3}$}

\begin{abstract}
In this study, the energy balance and Greenhouse Gas Emissions (GHG) of cotton cultivation in Bismil district of Diyarbakır province in Turkey was defined. The energy balance and GHG of cotton cultivation was computed by conducting face to face surveys with 73 farms in the 2018-2019 cultivation season, which were selected by simple random sampling method. The energy input and output in cotton cultivation were computed as $54617.62 \mathrm{MJ}^{-1} \mathrm{ha}^{-1}$ and $65984.42 \mathrm{MJ} \mathrm{ha}^{-1}$, respectively. Energy inputs occurs of electricity energy with $18608.40 \mathrm{MJ} \mathrm{ha}^{-1}$ (34.06\%), chemical fertilizers energy with $15254.67 \mathrm{MJ} \mathrm{ha}^{-1}$ (27.93\%), diesel fuel energy with 14364.68 (26.30\%), irrigation water energy with $3559.50 \mathrm{MJ} \mathrm{ha}^{-1}(6.53 \%)$, machinery energy with $1152.79 \mathrm{MJ} \mathrm{ha}^{-1}(2.11 \%)$, chemicals energy with $1075.76 \mathrm{MJ} \mathrm{ha}^{-1}(1.96 \%)$, seed energy with $307.98 \mathrm{MJ} \mathrm{ha}^{-1}(0.57 \%)$, human labour energy with $293.84 \mathrm{MJ}$ ha $^{-1}(0.54 \%)$, respectively. Total energy inputs in cotton cultivation can be classified as $67.43 \%$ direct, $32.57 \%$ indirect, $7.62 \%$ renewable and $92.38 \%$ non-renewable. Energy use efficiency, specific energy, energy productivity and net energy in cotton cultivation were computed as $1.21,9.77 \mathrm{MJ} \mathrm{kg}^{-1}, 0.10 \mathrm{~kg} \mathrm{MJ}^{-1}$ and $11366.80 \mathrm{MJ} \mathrm{ha}^{-1}$, respectively. Total GHG emissions were computed as $6482.36 \mathrm{kgCO}_{2 \text {-eq }} \mathrm{a}^{-1}$ for cotton cultivation with the greatest input part for electricity with $47.94 \%$ (3 $107.60 \mathrm{kgCO}_{2 \text {-eq }} \mathrm{a}^{-1}$ ). The electricity followed up nitrogen with $16.29 \%$ (1 $\left.055.67 \mathrm{kgCO}_{2 \text {-eq }} \mathrm{a}^{-1}\right)$, irrigation water with $14.82 \%\left(960.50 \mathrm{kgCO}_{2 \text {-eq }} \mathrm{ha}^{-1}\right)$, diesel fuel with $10.86 \%(704.08$ $\left.\mathrm{kgCO}_{2 \text {-eq }} \mathrm{ha}^{-1}\right)$, seed with $3.07 \%\left(199.14 \mathrm{kgCO}_{2 \text {-eq }} \mathrm{ha}^{-1}\right)$, chemicals with $2.28 \%\left(147.76 \mathrm{kgCO}_{\text {2-eq }} \mathrm{ha}^{-1}\right)$, phosphorous with $1.78 \%\left(115.64 \mathrm{kgCO}_{2 \text {-eq }} \mathrm{a}^{-1}\right)$, human labour with $1.62 \%\left(104.94 \mathrm{kgCO}_{2 \text {-eq }} \mathrm{Ca}^{-1}\right)$, machinery with $1.26 \%(81.85$ $\left.\mathrm{kgCO}_{2 \text {-eq }} \mathrm{ha}^{-1}\right)$ and potassium with $0.08 \%\left(5.18 \mathrm{kgCO}_{2 \text {-eq }} \mathrm{ha}^{-1}\right)$, respectively. Additionally, GHG ratio value was computed as $1.16 \mathrm{kgCO}_{2 \text {-eq }} \mathrm{kg}^{-1}$ in cotton cultivation.
\end{abstract}

Keywords: Energy use efficiency, Energy productivity, GHG ratio, Net energy, Specific energy

\footnotetext{
1*Sorumlu Yazar/Corresponding Author: Mehmet Firat Baran, Siirt University, Agriculture Faculty, Biosystem Engineering Department, Siirt, Turkey, E-mail: mfb197272@gmail.com (iD) OrcID: 0000-0002-7657-1227.

${ }^{2}$ Osman Gökdoğan, Isparta University of Applied Sciences, Agriculture Faculty, Agricultural Machinery and Technologies Engineering Department, Isparta, Turkey. E-mail: osmangokdogan@gmail.com DorcID: 0000-0002-4933-7144.

${ }^{2}$ Y1lmaz Bayhan, Tekirdağ Namık Kemal University, Agriculture Faculty, Biosystem Engineering Department, Tekirdağ, Turkey. E-mail: ybayhan@nku.edu.tr (iD) OrcID: 0000-0003-1099-3571.

Atıf/Citation: Baran, M.F., Gökdoğan, O., Yılmaz, Y. Determination of Energy Balance and Greenhouse Gas Emissions (GHG) of Cotton Cultivation in Turkey: A Case Study from Bismil District of Diyarbakır Province. Tekirda ğ Ziraat Fakültesi Dergisi, 18 (2), 322-332.
}

CBu çalışma Tekirdağ Namık Kemal Üniversitesi tarafından Creative Commons Lisansı (https://creativecommons.org/licenses/by-nc/4.0/) kapsamında yayınlanmıştır. Tekirdağ 2021 


\section{Özet}

Bu çalışmada Türkiye'nin Diyarbakır ilinin Bismil ilçesinde pamuk yetiştiriciliğinin enerji bilançosu ve sera gazı emisyonlarının belirlenmesi amaçlanmıştır. 2018-2019 yetiştiricilik sezonunda basit tesadüfi örnekleme yöntemine göre seçilen 73 işletme ile yüzyüze anket yapılarak pamuk yetiştiriciliğinin enerji bilançosu ve sera gazı emisyonu hesaplanmıştır. Pamuk yetiştiriciliğinde enerji girdisi ve enerji çıktısı sırasıyla $54617.62 \mathrm{MJ}^{-1} \mathrm{ha}^{-1}$ ve $65984.42 \mathrm{MJ} \mathrm{ha}^{-1}$ olarak hesaplanmıştır. Girdiler sırasıyla $18608.40 \mathrm{MJ} \mathrm{ha}^{-1}(34.06 \%)$ ile elektrik enerjisi, 15 254.67 $\mathrm{MJ} \mathrm{ha}^{-1}$ (27.93\%) ile kimyasal gübre enerjisi, 14364.68 (26.30\%) ile dizel yakıt enerjisi, $3559.50 \mathrm{MJ}^{-1}$ ${ }^{1}$ (6.53\%) ile sulama suyu enerjisi, $1152.79 \mathrm{MJ} \mathrm{ha}^{-1}(2.11 \%)$ ile makine enerjisi, $1075.76 \mathrm{MJ} \mathrm{ha}^{-1}(1.96 \%)$ ile kimyasal enerji, $307.98 \mathrm{MJ} \mathrm{ha}^{-1}(0.57 \%)$ ile tohum enerjisi, $293.84 \mathrm{MJ} \mathrm{ha}^{-1}(0.54 \%)$ ile insan işgücü enerjisinden oluşmaktadır. Pamuk yetiştiriciliğinde toplam girdi enerjisinin \%67.43'ü doğrudan, \%32.57'si dolaylı, \%7.62'si yenilenebilir ve $\% 92.38$ ' $\mathrm{i}$ ise yenilenemez olarak sınıflandırılabilir. Pamuk yetiştiriciliğinde enerji kullanım etkinliği, spesifik enerji, enerji verimliliği ve net enerji sırasıyla $1.21,9.77 \mathrm{MJ} \mathrm{kg}^{-1}, 0.10 \mathrm{~kg} \mathrm{MJ}^{-1}$ ve $11366.80 \mathrm{MJ}$ $\mathrm{ha}^{-1}$ olarak hesaplanmıştır. Pamuk yetiştiriciliğinde toplam sera gazı emisyonu $6482.36 \mathrm{kgCO}_{2 \text {-eş }} \mathrm{ha}^{-1}$ olarak hesaplanmış olup, en büyük oran \%47.94 (3 $\left.107.60 \mathrm{kgCO}_{2 \text {-eq }} \mathrm{ha}^{-1}\right)$ ile elektrik olarak hesaplanmıştır. Elektriği

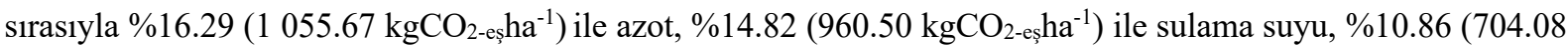
$\left.\mathrm{kgCO}_{2 \text {-eşha }}{ }^{-1}\right)$ ile dizel yakıt, \%3.07 (199.14 $\left.\mathrm{kgCO}_{2 \text {-eşha }}{ }^{-1}\right)$ ile tohum, \%2.28 (147.76 $\left.\mathrm{kgCO}_{2 \text {-esh }} \mathrm{ha}^{-1}\right)$ ile kimyasallar, \%1.78 (115.64 $\left.\mathrm{kgCO}_{2 \text {-esh }} \mathrm{ha}^{-1}\right)$ ile fosfor, \%1.62 (104.94 $\left.\mathrm{kgCO}_{2 \text {-eşh}}{ }^{-1}\right)$ ile insan işgücü, \%1.26 (81.85 $\left.\mathrm{kgCO}_{2 \text {-eşha }}{ }^{-1}\right)$ ile makine ve $\% 0.08\left(5.18 \mathrm{kgCO}_{2 \text {-eşha }}{ }^{-1}\right)$ ile potasyum takip etmiştir. Ayrıca pamuk yetiştiriciliğinde GHG oranı $1.16 \mathrm{kgCO}_{2 \text {-eş }} \mathrm{kg}^{-1}$ olarak hesaplanmıştır.

Anahtar Kelimeler: Enerji kullanım etkinliği, Enerji verimliliği, GHG oranı, Net enerji, Spesifik enerji 


\section{Introduction}

Cotton is one of the most important products in the world agriculture, industry and trade because of its very different and important utilization areas. In addition to the increasing world population, the increasing needs of human beings for consumption increase, the importance of this versatile plant day by day. Growing interest in natural fibers and rising living standards in the world increases the demand for cotton plants (Anonymous, 2020a). According to the data of the International Cotton Advisory Committee (ICAC), 32.825 million hectares of cotton were cultivated in the world in the 2018/19 cultivation period. In this season, $37 \%$ of the 32.825 million hectares of cotton cultivated in India. India is followed by the USA, China, Pakistan and Brazil in the width of the cultivation areas. As the result of the expansion of cotton cultivation areas in African countries in recent years, despite the grow, Turkey has ranked $11^{\text {th }}$ in terms of world cotton cultivation area (Anonymous, 2020b).

It is an important industrial plant that constitutes the raw materials with fiber in textile industry, oil obtained from its core in vegetable oil industry, aperture and pulp in animal feed industry, linters in paper, furniture and cellulose industry. Cotton is an important and strategic product that provides great benefits to our country's economy with this wide area of use, added value and employment opportunities. Due to these features, it has a contribution to the development of both agriculture and industry of the regions and countries grown (Anonymous, 2020c). Areas where have intensive cotton cultivation in Turkey; Aegean, Çukurova, Southeastern Anatolia Regions and Antalya. In the 2017/18 cotton season, in 502 thousand hectares 882 thousand tons of cotton fiber cultivation was made, and about 1 million 571 thousand tons of cotton was consumed in Turkey. In the 2017/18 cotton cultivation season, in return to 882 thousand tons of fiber cotton, 2.5 million tons of seed cotton was cultivated, and fiber cotton yield was $1820 \mathrm{~kg} \mathrm{ha}^{-1}$. Şanlıurfa, Aydın, Hatay, Diyarbakır, Adana and İzmir have 6 provinces in Turkey that meets $88 \%$ of cultivation, respectively. Şanllurfa province alone meets $42 \%$ of all production. The share of the other 23 cotton cultivating provinces in cultivation is between $0.1 \%$ and $1.3 \%$ (Anonymous, 2020d). Since cotton is a selective plant in terms of climate characteristics, it can be grown in limited places in our country (Karademir et al. 2015).

Semerci et al. (2019) reported that; "Agricultural production is widely mechanised which is powered by fossil fuels. Although this provides more income, it decreases the level of labor force usage. Especially in developed countries, fossil fuel usage levels in agricultural production are quite high, and the side effects of unconscious energy consumption makes planned energy consumption inevitable (Öztürk et al., 2015; Çelen, 2016)”. In order to evaluate productivity, it is a more practical approach to check the total energy value that is used in agricultural production, to the energy value that is used from agricultural production (Öztürk, 2011). In production efficiency is defined as the ratio of the sum of weighted outputs to the sum of weighted inputs or as the ratio of the actual output to the optimal output. The weights for inputs and outputs are guessed to the best benefit for each unit so as to maximize its relative efficiency (Mukherjee, 2008; Mousavi-Avval et al., 2011). Rising the usage of energy inputs in agriculture led to numerous environmental issues like high consumption of non-renewable energy resources, loss of biodiversity, pollution of the aquatic environment by the nutrients $\mathrm{N}$ and $\mathrm{P}$ as well as by pesticides (Nemecek et al., 2011; Khoshnevisan et al., 2013). Global warming is one of the most important subjects in the last time. Agricultural GHG emissions account for 10-12\% of all anthropogenic GHG emissions (Brown et al., 1998; Khoshnevisan et al., 2013).

Several studies were performed on cotton agriculture energy balance in agricultural production. Studies were done on energy balance of cotton (Singh et al., 2000; Y1lmaz et al. 2005; Ören and Öztürk, 2006; Polat et al. 2006; Dağıstan et al. 2009; Şehri 2012; Zahedi et al. 2014; Baran, 2016; Semerci et al., 2019). Many studies were performed on energy balance in agricultural products. For example, studies were done on energy use efficiency of maize (Konak et al., 2004), wheat (Tipi et al., 2009; Çiçek et al., 2011; Gökdoğan and Sevim, 2016; Unakıtan and Aydın, 2018), legume (Ertekin et al., 2010), lentil (Asakereh et al., 2010), corn silage (Barut et al., 2011), sunflower (Bayhan, 2016; Akdemir et al. 2017; Unakıtan and Aydın, 2018), chickpea (Marakoğlu and Çarman, 2009; Marakoğlu et al., 2010; Karaağaç et al., 2019), sesame (Baran and Gokdogan, 2017), tomato (Hatırlı et al., 2005; Esengün et al., 2007; Saltuk, 2019). For example, studies were performed on GHG of cotton (Pishgar-Komleh et al., 2012a), potato (Pisghar-Komleh et al., 2012b), wheat (Khoshnevisan et al., 2013), rice (Maraseni et al., 2018), 
field crops (Eren et al., 2019) etc. No studies related to the energy balance and GHG of cotton cultivation in Diyarbakır province has been covered in this study. In this study, it was aimed to define the energy balance and GHG in cotton cultivation in Bismil district of Diyarbakır province.

\section{Materials and Methods}

Diyarbakır province is in the central part of the Southeastern Anatolia Region at the northern end of Mesopotamia. Siirt, Muş from the east; Mardin from the south; Şanlıurfa, Adıyaman, Malatya from the west; It is surrounded by the provinces of Elazığ and Bingöl from the north. Its area is $1516200 \mathrm{~km}^{2}$, between 37.905199 and 40.231934 north latitudes and 40.37 and 41.20 east longitudes. It is surrounded by mountains that are not too high and its middle is hollow. It is covered with $37 \%$ of mountains and $31 \%$ of plains. The plains are suitable for agriculture and fertile. These fertile lands are irrigated by the Tigris River and its tributaries. It is $650 \mathrm{~m}$ above sea level. This height is $640 \mathrm{~m}$ in some places and $660 \mathrm{~m}$ in some places (Anonymous, 2020e). Main material of this study consisted of primary data that were collected from 73 cotton farms in Bismil district of Diyarbakır province in Turkey by face to face in 20182019 cultivation season. Data of the study were collected from cotton farms which were defined by the Simple Random Sampling Method. The equation 1 of the method that was used to define the sample size was given below (Çiçek and Erkan, 1996).

$\mathrm{n}=\frac{\mathrm{N} \times \mathrm{s}^{2} \times \mathrm{t}^{2}}{(\mathrm{~N}-1) \mathrm{d}^{2}+\left(\mathrm{s}^{2} \times \mathrm{t}^{2}\right)}$

In the formula; $\mathrm{n}$, is the required sample size; $\mathrm{N}$, the number of total farms in the region; $\mathrm{s}$, standard deviation; $\mathrm{t}$, the reliability coefficient (1.96 which represents, $95 \%$ confidence); d, acceptable error ( $5 \%$ deviation). The acceptable error value was defined to be $5 \%$, and the sample size was computed as 73 . In order to define the sample villages and farms, the Simple Random Sampling Method was used by means of data that were obtained from the Farmers' Registration System records of the Agriculture and Forestry Directorate. In Table 1, energy equivalents of inputs and output were given as energy values in cotton cultivation. Energy balance computations were performed to define the productivity levels of cotton cultivation. Input amounts were computed and then these inputs data were multiplied by the energy equivalent coefficient. When defining the energy equivalent coefficients, previous energy balance studies were used. By adding energy equivalents of all inputs in MJ unit, the total energy equivalent was defined. Energy use efficiency, specific energy, energy productivity and net energy were computed by using the following equations 2,3,4,5 (Mandal et al. 2002; Mohammadi et al. 2008; Mohammadi et al., 2010).

Energy use efficiency $=\frac{\text { Energy output }\left(\frac{\mathrm{MJ}}{\mathrm{ha}}\right)}{\text { Energy input }\left(\frac{\mathrm{MJ}}{\mathrm{ha}}\right)}$

Specific energy $=\frac{\text { Energy input }\left(\frac{\mathrm{MJ}}{\mathrm{ha}}\right)}{\text { Product output }\left(\frac{\mathrm{kg}}{\mathrm{ha}}\right)}$

Energy productivity $=\frac{\text { Product output }\left(\frac{\mathrm{kg}}{\mathrm{ha}}\right)}{\text { Energy input }\left(\frac{\mathrm{MJ}}{\mathrm{ha}}\right)}$

Net energy $=$ Energy output $\left(\mathrm{MJ} \mathrm{ha}^{-1}\right)-$ Energy input $\left(\mathrm{MJ} \mathrm{ha}^{-1}\right)$

In this study, greenhouse gas emissions (GHG) coefficients of inputs in cotton cultivation were given in Table 2. Eren et al. (2019) reported that; "The GHG emissions $\left(\mathrm{kgCO}_{2}\right.$-eqha $\left.{ }^{-1}\right)$ associated with the inputs to growing 1 ha of plant were calculated as following adapted by Hughes et al. (2011). $\sum$ where $\mathrm{R}(\mathrm{i})$ is the application rate of input $\mathrm{i}$ (unitinputha ${ }^{-1}$ ) and $\mathrm{EF}(\mathrm{i})$ is the GHG emission coefficient of input $\mathrm{i}\left(\mathrm{kgCO}_{2}\right.$-equnitinput $\left.{ }^{-1}\right)$. Morever, an index is defined to evaluate the amount of emitted $\mathrm{kgCO}_{2 \text {-eq }}$ per $\mathrm{kg}$ yield as following adapted Houshyar et al. (2015) and Khoshnevisan et al. (2014). Where $\mathrm{I}_{\mathrm{GHG}}$ is GHG ratio and $\mathrm{Y}$ is the yield as kg per ha".

$G H G_{h a}=\sum_{i=1}^{n} R(i) \times E F(i)$

$I_{G H G}=\frac{G H G_{h a}}{Y}$ 
Energy balance of cotton cultivation were defined were given in Table 3. Koçtürk and Engindeniz (2009) reported that; "The input energy can also be classified into direct and indirect, and renewable and non-renewable forms. The indirect energy consists of pesticide and fertilizer while the direct energy includes human and animal power, diesel and electricity energy used in the production process. On the other hand, non-renewable energy includes petrol, diesel, electricity, chemicals, fertilizers, machinery, while renewable energy consists of human and animal labour (Mandal et al. 2002; Singh et al. 2003)". Energy use efficiency computations in cotton cultivation were given in Table 4. Energy inputs of cotton cultivation in the form of direct, indirect, renewable and non-renewable energy were given in Table 5.

Table 1. Energy equivalents in cotton cultivation

\begin{tabular}{llcl}
\hline Inputs and outputs & Unit & $\begin{array}{c}\text { Energy equivalent } \\
\text { coefficient }\end{array}$ & References \\
\hline Inputs & Unit & Values (MJ unit $^{-1}$ ) & References \\
\hline Human labour & $\mathrm{h}$ & 1.96 & $\begin{array}{l}\text { Mani et al. 2007; } \\
\text { Karaağaç et al., 2011 }\end{array}$ \\
\hline Machinery & $\mathrm{h}$ & 64.80 & Singh 2002; Kizllaslan, 2009 \\
\hline & $\mathrm{kg}$ & Chemical fertilizers \\
\hline Nitrogen & $\mathrm{kg}$ & 60.60 & Singh 2002 \\
Phosphorous & $\mathrm{kg}$ & 6.110 & Singh 2002 \\
Potassium & $\mathrm{kg}$ & 101.20 & Singh 2002 \\
\hline Chemicals & $\mathrm{kg}$ & 120 & Yaldı et al. 1993 \\
\hline Microelements & $\mathrm{L}$ & 56.31 & Mandal et al., 2002; Singh, 2002; Çanakc1 \\
\hline Diesel fuel & $\mathrm{kWh}$ & 3.60 & Singh, 2002; Demircan et al. 2006 \\
\hline Electricity & $\mathrm{m}$ & 0.63 & Oakan et al., 2004 \\
\hline Irrigation water & $\mathrm{kg}$ & 11.80 & Singh, 2002; Y1lmaz et al. 2005; \\
\hline Seed & Unit & Values (MJ unit $\left.{ }^{-1}\right)$ & Reference \\
\hline Output & $\mathrm{kg}$ & 11.80 & Singh, 2002; Y1lmaz et al. 2005 \\
\hline Cotton & &
\end{tabular}

Table 2. Greenhouse gas (GHG) emissions coefficients in cotton cultivation

\begin{tabular}{|c|c|c|c|}
\hline Inputs & Unit & $\begin{array}{l}\text { GHG coefficient } \\
\left(\mathrm{kgCO}_{2 \text {-eq }} \text { unit }^{-1}\right)\end{array}$ & References \\
\hline Human labour & $\mathrm{h}$ & 0.700 & $\begin{array}{l}\text { Nguyen, T.L.T. and Hermansen, 2012; } \\
\text { Eren et al., } 2019\end{array}$ \\
\hline Machinery & MJ & 0.071 & $\begin{array}{l}\text { Pishgar-Komleh et al., 2012b; } \\
\text { Eren et al., } 2019\end{array}$ \\
\hline Nitrogen & $\mathrm{kg}$ & 4.570 & BioGrace-II, 2015; Eren et al., 2019 \\
\hline Phosphorous & $\mathrm{kg}$ & 1.180 & BioGrace-II, 2015; Eren et al., 2019 \\
\hline Potassium & $\mathrm{kg}$ & 0.640 & BioGrace-II, 2015; Eren et al., 2019 \\
\hline Chemicals & $\mathrm{kg}$ & 13.900 & BioGrace-II, 2015; Eren et al., 2019 \\
\hline Diesel fuel & $\mathrm{L}$ & 2.760 & Clark et al., 2016; Eren et al., 2019 \\
\hline $\begin{array}{l}\text { Electricity } \\
\text { (for Turkey) }\end{array}$ & MJ & 0.167 & BioGrace-II, 2015; Eren et al., 2019 \\
\hline Irrigation water & $\mathrm{m}^{3}$ & 0.170 & Lal, 2004; Eren et al., 2019 \\
\hline Seed & $\mathrm{kg}$ & 7.630 & Clark et al., 2016; Eren et al., 2019 \\
\hline
\end{tabular}

3. Results and Discussion

According to surveys in cotton farms, the average amount of cotton cultivated per hectare during 2018-2019 cultivation season was computed as $5591.90 \mathrm{~kg} \mathrm{ha}^{-1}$. If the average values are examined by referring to Table 3 , 
it can be seen that the highest energy inputs in cotton cultivation were electricity energy with $18608.40 \mathrm{MJ} \mathrm{ha}^{-1}$ (34.06\%), chemical fertilizers energy with $15254.67 \mathrm{MJ} \mathrm{ha}^{-1}$ (27.93\%), diesel fuel energy with $14364.68 \mathrm{MJ} \mathrm{ha}^{1}$ $(26.30 \%)$, irrigation water energy with $3559.50 \mathrm{MJ} \mathrm{ha}^{-1}(6.53 \%)$, machinery energy with $1152.79 \mathrm{MJ} \mathrm{ha}^{-1}(2.11 \%)$, chemicals energy with $1075.76 \mathrm{MJ} \mathrm{ha}^{-1}(1.96 \%)$, seed energy with $307.98 \mathrm{MJ} \mathrm{ha}^{-1}(0.57 \%)$, human labour energy with 293.84 MJ ha- ${ }^{-1}(0.54 \%)$, respectively. In previous studies, Singh et al. (2000), Dağıstan et al. (2009) and Baran (2016) concluded in their cotton study that the chemical fertilizers energy usage had the first part $51.32 \%$, $45.31 \%$ and $30.15 \%$ by respectively. Polat et al. (2006), Ören and Öztürk (2006) and Zahedi et al. (2014) concluded in their cotton study that the diesel fuel energy usage had the first part $27.47 \%, 41.24 \%$ and $47.40 \%$ by respectively. Yilmaz et al. (2005) concluded in their cotton study that the irrigation water energy usage had the first part $31.10 \%$, Semerci et al. (2019) concluded in their cotton study that the electricity energy usage had the first part $36.61 \%$.

Table 3. Energy balance in cotton cultivation

\begin{tabular}{|c|c|c|c|c|c|}
\hline Inputs & Unit & $\begin{array}{c}\text { Energy equivalent } \\
\text { (MJ unit }^{-1} \text { ) }\end{array}$ & $\begin{array}{c}\text { Input used } \\
\text { per hectare } \\
\left.(\text { unit ha' })^{-1}\right)\end{array}$ & $\begin{array}{c}\text { Energy } \\
\text { value } \\
\left(\mathrm{MJ} \mathrm{ha}^{-1}\right)\end{array}$ & $\begin{array}{c}\text { Ratio } \\
(\%)\end{array}$ \\
\hline Human labour & $\mathrm{h}$ & 1.96 & 149.92 & 293.84 & 0.54 \\
\hline Soil preparation & $\mathrm{h}$ & 1.96 & 8.13 & 15.94 & \\
\hline Sowing & $\mathrm{h}$ & 1.96 & 1.37 & 2.69 & \\
\hline Hoeing & $\mathrm{h}$ & 1.96 & 114.92 & 225.24 & \\
\hline Fertilization & $\mathrm{h}$ & 1.96 & 1.32 & 2.59 & \\
\hline Spraying & $\mathrm{h}$ & 1.96 & 6.78 & 13.29 & \\
\hline Irrigation & $\mathrm{h}$ & 1.96 & 14.28 & 27.99 & \\
\hline Harvest & $\mathrm{h}$ & 1.96 & 3.12 & 6.12 & \\
\hline Machinery & $\mathrm{h}$ & 64.80 & 17.79 & 1152.79 & 2.11 \\
\hline Soil preparation & $\mathrm{h}$ & 64.80 & 5.12 & 331.78 & \\
\hline Sowing & $\mathrm{h}$ & 64.80 & 1.11 & 71.93 & \\
\hline Hoeing & $\mathrm{h}$ & 64.80 & 3.69 & 239.11 & \\
\hline Fertilization & $\mathrm{h}$ & 64.80 & 1.21 & 78.41 & \\
\hline Spraying & $\mathrm{h}$ & 64.80 & 4.71 & 305.21 & \\
\hline Harvest & $\mathrm{h}$ & 64.80 & 1.95 & 126.36 & \\
\hline Chemicals & $\mathrm{kg}$ & 101.20 & 10.63 & 1075.76 & 1.96 \\
\hline Chemical fertilizers & & & & 15254.67 & 27.93 \\
\hline Nitrogen & $\mathrm{kg}$ & 60.60 & 231 & 13998.60 & \\
\hline Phosphorous & $\mathrm{kg}$ & 11.10 & 98 & 1087.80 & \\
\hline Potassium & $\mathrm{kg}$ & 6.70 & 8.10 & 54.27 & \\
\hline Microelements & $\mathrm{kg}$ & 120 & 0.95 & 114 & \\
\hline Diesel fuel & $\mathrm{L}$ & 56.31 & 255.10 & 14364.68 & 26.30 \\
\hline Electricity & $\mathrm{kWh}$ & 3.60 & 5169 & 18608.40 & 34.06 \\
\hline Irrigation water & $\mathrm{m}^{3}$ & 0.63 & 5650 & 3559.50 & 6.53 \\
\hline Seed & $\mathrm{kg}$ & 11.80 & 26.10 & 307.98 & 0.57 \\
\hline Total inputs & & & & 54617.62 & 100 \\
\hline Output & Unit & $\begin{array}{c}\text { Energy equivalent } \\
\left(\text { MJ unit }{ }^{-1}\right)\end{array}$ & $\begin{array}{c}\text { Output per } \\
\text { hectare } \\
\left(\text { unit ha }^{-1}\right)\end{array}$ & $\begin{array}{c}\text { Energy } \\
\text { value } \\
\left(\mathrm{MJ} \mathrm{ha}^{-1}\right)\end{array}$ & $\begin{array}{c}\text { Ratio } \\
(\%)\end{array}$ \\
\hline Cotton & $\mathrm{kg}$ & 11.80 & 5591.90 & 65984.42 & 100 \\
\hline Total output & & & & 65984.42 & 100 \\
\hline
\end{tabular}

Cotton, energy input, energy output, energy use efficiency, specific energy, energy productivity and net energy in cotton plant cultivation were computed as $5591.90 \mathrm{~kg} \mathrm{ha}^{-1}, 54617.62 \mathrm{MJ} \mathrm{ha}^{-1}, 65984.42 \mathrm{MJ} \mathrm{ha}^{-1}, 1.21,9.77$ $\mathrm{MJ} \mathrm{kg}^{-1}, 0.10 \mathrm{~kg} \mathrm{MJ}^{-1}$ and $11366.80 \mathrm{MJ} \mathrm{ha}^{-1}$, respectively (Table 4). In previous studies, Singh et al. (2000) defined energy use efficiency as 10.20, Y1lmaz et al. (2005) as 0.74, Ören and Öztürk (2006) as 2.38, Polat et al. (2006) 
as 2.52, Dağıstan et al. (2009) as 2.36, Şehri (2012) as 1.63, Zahedi et al. (2014) as 0.70, Baran (2016) as 3.79, Semerci et al. (2019) as 1.11, respectively.

Table 4. Energy use efficiency computations in cotton cultivation

\begin{tabular}{lcc}
\hline Computations & Unit & Values \\
\hline Cotton & $\mathrm{kg} \mathrm{ha}^{-1}$ & 5591.90 \\
Energy input & $\mathrm{MJ} \mathrm{ha}^{-1}$ & 54617.62 \\
Energy output & $\mathrm{MJ} \mathrm{ha}^{-1}$ & 65984.42 \\
Energy use efficiency & & 1.21 \\
Specific energy & $\mathrm{MJ} \mathrm{kg}^{-1}$ & 9.77 \\
Energy productivity & $\mathrm{kg} \mathrm{MJ}^{-1}$ & 0.10 \\
Net energy & $\mathrm{MJ} \mathrm{ha}^{-1}$ & 11366.80 \\
\hline
\end{tabular}

The part of energy inputs, used in the cotton cultivation, in accordance with the direct, indirect, renewable and non-renewable energy groups were given in Table 5. As can be examined from Table 5, the total energy input used in cotton cultivation can be classified as $67.43 \%$ direct and $32.57 \%$ indirect. As can be examined from Table 5, the total energy input used in cotton cultivation can be classified as $7.62 \%$ renewable and $92.38 \%$ non-renewable. Similarly, it was defined that the ratio of non-renewable energy was higher than the ratio of renewable energy in cotton Singh et al. (2000), cotton (Y1lmaz et al., 2005), cotton (Ören and Öztürk, 2006), cotton (Polat et al., 2006), cotton (Dağıstan et al., 2009), cotton (Şehri, 2012), cotton (Zahedi et al., 2014), cotton (Baran 2016), cotton (Semerci et al., 2019). Greenhouse gas emissions (GHG) of inputs in cotton cultivation were given Table 6.

Table 5. Energy inputs types for cotton cultivation

\begin{tabular}{lcc}
\hline Type of energy & Energy input (MJ ha $\left.{ }^{-\mathbf{1}}\right)$ & Ratio (\%) \\
\hline Direct energy $^{\mathrm{a}}$ & 36826.42 & 67.43 \\
Indirect energy $^{\mathrm{b}}$ & 17791.20 & 32.57 \\
\hline Total & $\mathbf{5 4 6 1 7 . 6 2}$ & $\mathbf{1 0 0}$ \\
\hline Renewable energy $^{\mathrm{c}}$ & 4161.32 & 7.62 \\
Non-renewable energy $^{\mathrm{d}}$ & 50456.30 & 92.38 \\
\hline Total & $\mathbf{5 4 6 1 7 . 6 2}$ & $\mathbf{1 0 0}$ \\
\hline
\end{tabular}

Table 6. Greenhouse gas emissions (GHG) of inputs in cotton cultivation

\begin{tabular}{|c|c|c|c|c|c|}
\hline Inputs & Unit & $\begin{array}{l}\text { GHG coefficient } \\
\left(\mathrm{kgCO}_{2 \text {-equnit }}{ }^{-1}\right)\end{array}$ & $\begin{array}{c}\text { Input used } \\
\text { per area } \\
(\text { unit ha-1) }\end{array}$ & $\begin{array}{c}\text { GHG emissions } \\
\left(\mathrm{kgCO}_{2-\mathrm{eq}} \mathrm{ha}^{-1}\right)\end{array}$ & $\begin{array}{c}\text { Ratio } \\
(\%)\end{array}$ \\
\hline Human labour & $\mathrm{h}$ & 0.700 & 149.92 & 104.94 & 1.62 \\
\hline Machinery & MJ & 0.071 & 1152.79 & 81.85 & 1.26 \\
\hline Nitrogen & $\mathrm{kg}$ & 4.570 & 231 & 1055.67 & 16.29 \\
\hline Phosphorous & $\mathrm{kg}$ & 1.180 & 98 & 115.64 & 1.78 \\
\hline Potassium & $\mathrm{kg}$ & 0.640 & 8.10 & 5.18 & 0.08 \\
\hline Chemicals & $\mathrm{kg}$ & 13.900 & 10.63 & 147.76 & 2.28 \\
\hline Diesel fuel & $\mathrm{L}$ & 2.760 & 255.10 & 704.08 & 10.86 \\
\hline Electricity & $\mathrm{MJ}$ & 0.167 & 18608.40 & 3107.60 & 47.94 \\
\hline Irrigation water & $\mathrm{m}^{3}$ & 0.170 & 5650 & 960.50 & 14.82 \\
\hline Seed & $\mathrm{kg}$ & 7.630 & 26.10 & 199.14 & 3.07 \\
\hline Total & & & & 6482.36 & 100 \\
\hline GHG ratio (per kg) & & & & 1.16 & \\
\hline
\end{tabular}

Total GHG emissions were computed as $6482.36 \mathrm{kgCO}_{2 \text {-eq }} \mathrm{ha}^{-1}$ for cotton cultivation with the greatest input part for electricity (47.94\%). The electricity followed up nitrogen (16.29\%), irrigation water (14.82\%), diesel fuel (10.86\%), seed (3.07\%), chemicals (2.28\%), phosphorous (1.78\%), human labour (1.62\%), machinery $(1.26 \%)$ 
and potassium ( $0.08 \%$ ), respectively. Additionally, GHG ratio value was computed as $1.16 \mathrm{kgCO}_{\text {-eq }} \mathrm{kg}^{-1}$ in cotton cultivation. In previous studies, Pishgar-Komleh et al. (2012a) computed the total GHG emission of cotton cultivation as $1195 \mathrm{kgCO}_{2 \text {-eq }} \mathrm{ha}^{-1}$, Pishgar-Komleh et al. (2012b) computed the total GHG emission of potato cultivation as $992.88 \mathrm{kgCO}_{2 \text {-eqha }}{ }^{-1}$, Khoshnevisan et al. (2013) computed the total GHG emission of wheat cultivation as $2711.58 \mathrm{kgCO}_{2}$-eqha ${ }^{-1}$, Mohammadi-Barsari et al. (2016) computed the total GHG emission of watermelon cultivation as $461.41 \mathrm{kgCO}_{2}$-eqha ${ }^{-1}$, Eren et al. (2019) computed the total GHG emission of sugar beet cultivation as $4742.69 \mathrm{kgCO}_{2 \text {-eqha }}{ }^{-1}$ etc.

\section{Conclusions}

Based on this study following conclusions were defined on cotton cultivation.

The energy inputs of electricity energy $18608.40 \mathrm{MJ} \mathrm{ha}^{-1}$ (34.06\%), chemical fertilizers energy with $15254.67 \mathrm{MJ}$ $\mathrm{ha}^{-1}(27.93 \%)$ and diesel fuel energy with $14364.68(26.30 \%)$ were the first, second and third part in the total energy inputs. Reducing of the electricity usage, chemical fertilizers usage and diesel fuel usage are the most suitable ways of energy management in this study.

Energy use efficiency, specific energy, energy productivity and net energy in cotton cultivation were computed as $1.21,9.77 \mathrm{MJ} \mathrm{kg}^{-1}, 0.10 \mathrm{~kg} \mathrm{MJ}^{-1}$ and $11366.80 \mathrm{MJ} \mathrm{ha}^{-1}$, respectively. Total energy inputs in cotton cultivation can be classified as $67.43 \%$ direct, $32.57 \%$ indirect, $7.62 \%$ renewable and $92.38 \%$ non-renewable. Reducing of chemical fertilizers (nitrogen, phosphorous and potassium) inputs and increasing of energy use efficiency is important for energy balance. Thus, farmyard manure usage should be increased.

Total GHG emissions were computed as $6482.36 \mathrm{kgCO}_{2 \text {-eq ha }}{ }^{-1}$ for cotton cultivation with the greatest part for electricity $3107.60 \mathrm{kgCO}_{\text {2-eqha }} \mathrm{ha}^{-1}(47.94 \%)$. The electricity followed up nitrogen $1055.67 \mathrm{kgCO}_{\text {2-eqha }}{ }^{-1}(16.29 \%)$, irrigation water $960.50 \mathrm{kgCO}_{2 \text {-eq }} \mathrm{ha}^{-1}(14.82 \%)$, the second and third part in the total GHG emissions, respectively.

Applying soil analysis to specify the soil fertilizer needs (to reduce high chemical fertilizer energy usage and GHG emissions), usage efficient electric pumps for irrigation, changing the traditionally irrigation systems to modern ones and usage wheat variety with high productivity are strongly submitted (Khoshnevisan et al., 2013). By following these recommendations yield and energy ratio will increase in cotton cultivation.

\section{Acknowledgment}

We would like to thank the cotton producers who supported us in the survey. 


\section{References}

Akdemir, S., Calavaris, C., Gemtos, T. (2017). Energy balance of sunflower production. Agronomy Research, 15(4): 1463-1473.

Anonymous, (2020a). T.C. Kalkınma Bakanlığı, Karacadağ Kalkınma Ajansı. Diyarbakır ve Şanlıurfa İllerinde Pamuk Sektörü Envanterinin Hazırlanması Projesi (Başbağ, S., Ekinci, R., Akıncı, C., Akın, S., Öcal Kara, F., Tonçer, Ö.) https://www.karacadag.gov.tr/Dokuman/Dosya/www.karacadag.org.tr_8_WH3D93PC_diyarbakir_ve_sanliurfa_illerinde_pamuk_sektor u_envanterinin_hazirlanmasi_projesi.pdf, (accessed date: 21.01.2020).

Anonymous, (2020b). T.C. Ticaret Bakanlığı. Esnaf, Sanatkarlar ve Kooperatifçilik Genel Müdürlüğ̈̈. 2018 Yılı Pamuk Raporu. Nisan, 2019. https://ticaret.gov.tr/data/5d41e59913b87639ac9e02e8/d0e2b9c79234684ad29baf256a0e7dce.pdf, (accessed date: 02.05.2020).

Anonymous, (2020c). TMMOB. Ziraat Mühendisleri $\quad$ Odasi. http://www.zmo.org.tr/genel/bizden detay.php?kod=30467\&tipi=17\&sube=0 , (accessed date: 21.01 .2020$)$.

Anonymous, (2020d). T.C. Tarım ve Orman Bakanlığı. Tarımsal Ekonomi ve Politika Geliştirme Enstitüsü. Tarım Ürünleri Piyasaları, Pamuk.https://arastirma.tarimorman.gov.tr/tepge/Belgeler/PDF $\% 20 \mathrm{Tar} \% \mathrm{C} 4 \% \mathrm{~B} 1 \mathrm{~m} \% 20 \% \mathrm{C} 3 \% 9 \mathrm{Cr} \% \mathrm{C} 3 \% \mathrm{BCnleri} \% 20 \mathrm{Piyasalar} \% \mathrm{C} 4 \% \mathrm{~B}$ 1/2019-Ocak\%20Tar\%C4\%B1m\%20\%C3\%9Cr\%C3\%BCnleri\%20Raporu/2019-Ocak\%20Pamuk.pdf, (accessed date: 21.01.2020).

Anonymous, (2020e). T.C. Kültür ve Turizm Bakanlığ1, Diyarbakır İl Kültür ve Turizm Müdürlüğü. http://www.diyarbakirkulturturizm.gov.tr/TR-56881/cografya.html, (accessed date: 01.05.2020).

Asakereh, A., Shiekhdavoodi, M.J., Safaieenejad, M. (2010). Energy consumption pattern of organic and conventional lentil in Iran a case study: Kuhdasht county. Asian Journal of Agricultural Sciences 2(3): 111-116.

Banaeian, N., Omid, M., Ahmadi, H. (2011). Energy and economic analysis of greenhouse strawberry production in Tehran province of Iran. Energy Conversion and Management 52: 1020-1025.

Baran, M.F. (2016). Energy efficiency analysis of cotton production in Turkey: A case study for Adiyaman province. American-Eurasian J. Agric. \& Environ. Sci. 16 (2): 229-233.

Baran, M.F., Gokdogan, O. (2017). Determination of energy use efficiency of sesame production. Tekirdağ Ziraat Fakültesi Dergisi 14(3): 7379.

Barut, Z.B., Ertekin, C., Karaağaç, H.A. (2011). Tillage effects on energy use for corn silage in Mediterranean Coastal of Turkey. Energy 36: 5466-5475.

Bayhan, Y. (2016). İkinci ürün ayçiçeği üretiminde farklı toprak işleme ve doğrudan ekim yöntemlerinin enerji kullanım etkinliğinin karşılaştırılması. Tekirdă̆ Ziraat Fakültesi Dergisi 13(2): 102-109.

Brown, L.R., Flavin, C.F., French, H. (1998). State of the world. New York: WW. Norton. p. 251.

BioGrace-II. (2015). Harmonised calculations of biofuel greenhouse gas emissions in Europe. BioGrace, Utrecht, The Netherlands. (http://www.biograce.net).

Clark, S., Khoshnevisan, B., Sefeedpari, P. (2016). Energy efficiency and greenhouse gas emissions during transition to organic and reducedinput practices: Student farm case study. Ecological Engineering 88: 186-194.

Çanakcı, M., Akınc1, İ. (2006). Energy use pattern analyses of greenhouse vegetable production. Energy 86: 1354-1358.

Çelen, İ.H. (2016). Tarımsal uygulamalarda enerji kullanımı üzerine bir değerlendirme. Electronic Journal of Vocational Colleges. December 2016: 18-29.

Çiçek, A., Erkan, O. (1996). Tarım Ekonomisinde Araştırma ve Örnekleme Yöntemleri. GOPÜ, Ziraat Fakültesi Yayınları No: 12, Ders Notları Serisi No: 6, Tokat.

Çiçek, A., Altıntaş, G., Erdal, G. (2011). Energy consumption patterns and economic analysis of irrigated wheat and rainfed wheat production: Case study for Tokat region, Turkey. Bulgarian Journal of Agricultural Science 17(3): 378-388.

Dağıstan, E., Akçaöz, H., Demirtaş, B., Yılmaz, Y. (2009). Energy usage and benefit-cost analysis of cotton production in Turkey. African Journal of Agricultural Research 4 (7): 599-604.

Demircan, V., Ekinci, K., Keener, H. M., Akbolat D. \& Ekinci, C. (2006). Energy and economic analysis of sweet cherry production in Turkey: A case study from Isparta province. Energy Conversion and Management 47: 1761-1769.

Eren, Ö., Gökdoğan, O. Baran, M.F. (2019). Determination of greenhouse gas emissions (GHG) in the production of different plants in Turkey. Fresenius Environmental Bulletin 28 (2A): 1158-1166.

Ertekin, C., Çanakcı, M., Külcü, R., Yaldız, O. (2010). Energy use in legume cultivation in Turkey. XVII ${ }^{\text {th }}$ World Congress of the International Commission of Agricultural and Biosystems Engineering (CIGR). Québec, Canada, June, 13-17, 1-9.

Esengün, K., Erdal, G., Gündüz, O., Erdal, H. (2007). An economic analysis and energy use in stake-tomato production in Tokat province of Turkey. Renewable Energy 32: 1873-1881. 
Gökdoğan, O., Sevim, B. (2016). Determination of energy balance of wheat production in Turkey: A case study of Eskil district of Aksaray province. Tekirdağ Ziraat Fakültesi Dergisi 13(4): 36-43.

Hatırl, S.A., Özkan, B., Fert, C. (2005). Energy inputs and crop yield relationship in greenhouse tomato production. Renewable Energy 31: $427-438$.

Hughes, D.J., West, J.S., Atkins, S.D., Gladders, P., Jeger, M.J., Fitt, B.D. (2011). Effects of disease control by fungicides on greenhouse gas emissions by U.K. arable crop production. Pest Manag. Sci. 67: 1082-1092.

Houshyar, E., Dalgaard, T., Tarazgar, M.H., Jorgensen, U. (2015). Energy input for tomato production what economy says, and what is good for the environment. Journal of Cleaner Production 89: 99-109.

Karaağaç, H.A., Aykanat, S., Cakır, B., Eren, Ö., Turgut, M. M., Barut, Z.B., Öztürk, H. H. (2011). Energy balance of wheat and maize crops production in Haciali Undertaking. 1 $1^{\text {th }}$ International Congress on Mechanization and Energy in Agriculture Congress. 388-391.

Karaağaç, H.A., Baran, M.F., Mart, D., Bolat, A., Eren, Ö. (2019). Nohut üretiminde enerji kullanım etkinliği ve sera gazı (GHG) emisyonunun belirlenmesi (Adana ili örneği). Avrupa Bilim ve Teknoloji Dergisi 16: 41-50.

Karademir, E., Karademir, C.., Ekinci, R, Sevilmiş, U. (2015). İleri generasyondaki pamuk (Gossypium hirsutum L.) hatlarında verim ve lif kalite özelliklerinin belirlenmesi. Türkiye Tarımsal Araştırmalar Dergisi 2 (2): 100-107.

Khoshnevisan, B., Rafiee, S., Omid, M., Yousefi, M., Movahedi, M. (2013). Modeling of energy consumption and GHG (greenhouse gas) emissions in wheat production in Esfahan province of Iran using artificial neural networks. Energy 52: 333-338.

Khoshnevisan, B., Shariati, H.M., Rafiee, S., Mousazadeh, H. (2014). Comparison of energy consumption and GHG emissions of open field and greenhouse strawberry production. Renewable and Sustainable Energy Reviews 29: 316-324.

Kızlaslan, H. (2009). Input-output energy analysis of cherries production in Tokat province of Turkey. Applied Energy 86: 1354-1358.

Koçtürk, O.M., Engindeniz, S. (2009) Energy and cost analysis of sultana grape growing: A case study of Manisa, west Turkey. African Journal of Agricultural Research 4 (10): 938-943.

Konak, M., Marakoğlu, T., Özbek, O. (2004) Mısır üretiminde enerji bilançosu. Selçuk Üniversitesi Ziraat Fakültesi Dergisi 18 (34): 28-30.

Lal, R. (2004). Carbon emission from farm operations. Environment International 30: 981-990.

Mani, I., Kumar, P., Panwar, J. S., Kant, K. (2007). Variation in energy consumption in production of wheat-maize with varying altitudes in hill regions of Himachal Prades, India. Energy 32: 2336-2339.

Mandal, K. G., Saha, K. P., Ghosh, P. K., Hati, K. M. \& Bandyopadhyay, K. K. (2002). Bioenergy and economic analysis of soybean based crop production systems in central India. Biomass and Bioenergy 23: 337-45.

Marakoğlu, T., Çarman, K. (2009). nohut tarımında farklı üretim tekniklerinin enerji bilançosu. Selçuk Üniversitesi Selçuk Tarım ve Gıda Bilimleri Dergisi 23 (48): 47-50.

Marakoğlu, T., Özbek, O., Çarman, K. (2010). Nohut üretiminde farklı toprak işleme sistemlerinin enerji bilançosu. Tarım Makinaları Bilimi Dergisi 6 (4): 229-235.

Maraseni, T.N., Deo, R.C., Qu, J., Gentle, P., Neupane, P.R. (2018). An international comparison of rice consumption behaviours and greenhouse gas emissions from rice production. Journal of Cleaner Production 172: 2288-2300.

Mohammadi, A., Tabatabaeefar, A., Shahin, S., Rafiee, S., Keyhani, A. (2008). Energy use and economical analysis of potato production in Iran a case study: Ardabil province. Energy Conversion and Management 49: 3566-3570.

Mohammadi, A., Rafiee, S., Mohtasebi, S.S., Rafiee, H. (2010). Energy inputs-yield relationship and cost analysis of kiwifruit production in Iran. Renewable Energy 35: 1071-1075.

Mohammadi-Barsari, A., Firouzi, S., Aminpanah, H. (2016). Energy-use pattern and carbon footprint of rain-fed watermelon production in Iran. Information Processing in Agriculture 3: 69-75.

Mousavi-Avval, S.H., Rafiee, S., Mohammadi, A. (2011). Optimization of energy consumption and input costs for apple production in Iran using data envelopment analysis. Energy 36: 909-916

Mukherjee, K. (2008). Energy use efficiency in the Indian manufacturing sector: an interstate analysis. Energy Policy 36 (2): $662-72$.

Nemecek, T., Dubois, D., Huguenin-Elie, O., Gaillard, G. (2011). Life cycle assessment of Swiss farming systems: I. Integrated and organic farming. Agriculture Systems 104: 217-32.

Nguyen, T.L.T., Hermansen, J.E. (2012). System expansion for handling co-products in LCA of sugar cane bio-energy systems: GHG consequences of using molasses for ethanol production. Applied Energy 89: 254-261.

Özkan, B., Kürklü, A., Akçaöz, H. (2004). An input-output energy analysis in greenhouse vegetable production: A case study for Antalya region of Turkey. Biomass and Bioenergy 26: 89-95

Ören, M.N., Öztürk, H.H. (2006). An analysis of energy utilization for sustainable wheat and cotton production in Southeastern Anatolia Region of Turkey. Journal of Sustainable Agriculture 29 (1): 119-130.

Öztürk, H.H. (2011). Bitkisel Üretimde Enerji Yönetimi. Hasad Yayıncılık, Ankara. 256, ISBN: 978-975-8377-78-7. 
Baran \& Gökdoğan \& Bayhan Determination of Energy Balance and Greenhouse Gas Emissions (GHG) of Cotton Cultivation in Turkey: A Case Study from Bismil District of Diyarbakır

Öztürk, H.H., Yaşar, B., Eren, Ö. (2015). Tarımda enerji kullanımı ve yenilenebilir enerji kaynakları.
www.zmo.org.tr/resimler/ekler/ce30eeb956b8bbd_ek.pdf .

Pishgar-Komleh, S.H., Sefeedpari, P., Ghahderijani, M. (2012a). Exploring energy consumption and $\mathrm{CO}_{2}$ emission of cotton production in Iran. J Renewable Sustainable Energy 4 (3): 33115.

Pishgar-Komleh, S.H., Ghahderijani, M., Sefeedpari, P. (2012b). Energy consumption and $\mathrm{CO}_{2}$ emissions analysis of potato production based on different farm size levels in Iran. Journal of Cleaner Production 33: 183-191.

Polat, R., Çopur, O., Sağlam, R. \& Sağlam, C. (2006). Energy use pattern and cost analysis of cotton agriculture: A case study for Sanliurfa, Turkey. The Philippine Agricultural Scientist 89 (4): 368-371.

Saltuk, B. (2019). Energy efficiency of greenhouse tomato production in Turkey: A case of Siirt province. Fresenius Environmental Bulletin 28 (8): 6352-6357.

Semerci A., Baran, M.F., Gokdoğan, O. Çelik, A.D. (2019). Determination of energy use efficiency of cotton production in Turkey: A Case Study From Hatay Province, Fresenius Environmental Bulletin 27 (4): 1829-1835.

Singh, S., Singh, S., Pannu, C.J.S., Singh, J. (2000). Optimization of energy input for raising cotton crop in Punjab. Energy Conversion \& Management 41: 1851-1861.

Singh, J. M. (2002). On farm energy use pattern in different cropping systems in Haryana, India. International Institute of Management University of Flensburg, Sustainable Energy Systems and Management. Master of Science Thesis, Germany.

Singh, H., Mishra, D., Nahar, N. M. \& Ranjan M. (2003). Energy use pattern in production agriculture of a typical village in Arid Zone India (Part II). Energy Conversion and Management 44: 1053-1067.

Şehri, M. (2012). Adana yöresi pamuk üretiminde enerji kullanım etkinliği ve maliyet analizi. (Yüksek Lisans Tezi) Çukurova Üniversitesi. Fen Bilimleri Enstitüsü, Adana.

Tipi, T., Çetin, B., Vardar, A. (2009). An analysis of energy use and input costs for wheat production in Turkey. Journal of Food, Agriculture and Environment 7(2): 352-356.

Unakitan, G., Aydın, B. (2018). A comparison of energy use efficiency and economic analysis of wheat and sunflower production in Turkey: A case study in Thrace Region. Energy 149: 279-285.

Yaldız, O., Öztürk, H.H., Zeren, Y., Başçetinçelik, A. (1993). Energy usage in production of field crops in Turkey. $5^{\text {th }}$ international congress on mechanization and energy in agriculture, Kusadasi, Turkey. October, 11-14, pp. 527-536 (in Turkish).

Yılmaz, I., Akçaöz, H., Özkan, B. (2005). An Analysis of energy use and input costs for cotton production in Turkey. Renewable Energy 30 (2005): 145-155.

Zahedi, M., Eshghizadeh, H.R., Mondani, F. (2014) Energy use efficiency and economical analysis in cotton production system in an arid region: A case study for Isfahan province, Iran. International Journal of Energy Economics and Policy 4 (1): $43-52$. 